\title{
EL CONTROL DE LOS PETRISTAS: INTEGRACIÓN Y SEGREGACIÓN EN LOS INICIOS DEL REINADO DE ENRIQUE DE TRASTÁMARA
}

\author{
Covadonga Valdaliso Casanova ${ }^{1}$
}

\section{RESUMEN}

La demanda sostenida por Juan de Gante, duque de Lancáster, del trono de Castilla en nombre de su esposa Constanza, hija del rey don Pedro, fue llevada adelante gracias al constante apoyo y empuje de los "petristas», un grupo de partidarios de Pedro I que, tras la muerte del monarca, se negaron a aceptar a Enrique de Trastámara como rey. En este artículo se aborda una aproximación a los orígenes de este movimiento entendiendo que su existencia representó un paso en el proceso de construcción de la llamada «monarquía Trastámara».

Palabras clave: petrismo, petristas, monarquía Trastámara, Castilla, siglo XIV.

\section{ABSTRACT}

The demand of John of Gaunt, Duke of Lancaster, of the throne of Castile on behalf of his wife Constance, daughter of King Peter I, was carried out thanks to the constant push of the "petristas", a group of supporters of Pedro I that refused to accept Henry of Trastamara as king after the death of the monarch. This paper discusses an approach to the origins of this movement understanding that its existence represented a phase in the process of building of the so-called "Trastamara monarchy."

Keywords: petrismo, petristas, Trastamara monarchy, Castile, $14^{\text {th }}$ century.

1 Doctora en Historia. Becaria Post-doctoral en el Centro de História da Sociedade e da Cultura. Faculdade de Letras. Universidade de Coimbra. Largo da Porta Férrea, 3004530 Coimbra (Portugal). C.e. covaldaliso@gmail.com 
La historia oficial, relato de los vencedores, no oculta, y apenas disfraza, que fue un suceso puntual, absolutamente irregular e innegablemente ilegítimo, el que en una fecha imprecisa del mes de marzo del año 1366 determinó el porvenir del reino de Castilla. Enrique, conde de Trastámara, hijo bastardo de Alfonso XI y en casi constante rebeldía desde que en el año 1350 Pedro I heredara el trono, acababa de atravesar la frontera aragonesa. Su objetivo era luchar, una vez más, contra su medio hermano. Le acompañaban mercenarios formados en las campañas de la Guerra de los Cien Años y desocupados en época de treguas. El cronista Pedro López de Ayala lo cuenta del siguiente $\operatorname{modo}^{2}$ :

Ouieron ally en Calahorra todos su acuerdo e su consejo. E de todas las gentes de estrangeros que ally venian eran los que hordenauan todo el fecho dos, por quanto auian visto muchos fechos de armas e de guerra, los quales eran el vno mossen Beltran de Claquin, que era breton del señorio del rrey de Françia, e el otro mossen Hugo de Carualoy, que era ingles de Ingla terra. E estos e todos los otros estrangeros dixeron al conde don Enrrique que, pues tan nobles gentes commo aquellos que venian con el eran acordados de lo guardar e tener por mayor en esta caualgada, e el auia cobrado vna çibdat de Castilla, que le rrogauan que se fiziesse llamar rrey de Castilla e tomasse titulo de rrey. (...) E luego que llego alli en la dicha çibdat de Calahorra le nonbraron rrey, e andudieron por la çibdat llamando «Real por el rrey don Enrrique». E luego los que alli venian con el le demandaron muchos donadios e merçedes en los rregnos de Castilla e de Leon, e otorgogelos de muy buen talante, ca assi le cunplia e avn estauan por cobrar. E luego que esto assi fue fecho el dicho conde de aqui en adelante se fizo llamar rrey.

Pese a tratarse de una versión de los hechos confeccionada décadas después con el objetivo de asentar los cimientos de la nueva dinastía, el texto de Ayala deja claro que fueron extranjeros los que animaron a Enrique a proclamarse rey, esperando ver compensado su apoyo con las, con el tiempo famosas, «mercedes enriqueñas». En la escena no se rodea al monarca de castellanos ni se sugiere siquiera un atisbo de elección de un nuevo rey por parte del reino. Nada de lo que ocurrió ese día casaba con la esencia de la monarquía castellana medieval, vitalicia y hereditaria.

Con todo, la crónica en su conjunto justifica, en buena medida, la autoproclamación. La negativa imagen del rey don Pedro trazada en sus páginas casa bastante bien con los primeros argumentos creados por Enrique para

2 Año XVII (1366), capítulo 3. Citamos a partir de la edición de ORDUNA, G. y MOURE, J.L., Crónica del Rey Don Pedro y delRrey Don Enrique, su hermano, hijos del rey don Alfonso Onceno, Vol. 1, Buenos Aires, SECRIT, 1994, y Crónica del Rey Don Pedro y delRrey Don Enrique, su hermano, hijos del rey don Alfonso Onceno, Vol. 2. Buenos Aires, SECRIT, 1997. 
ilegitimar el gobierno de su medio hermano. En el relato, concebido bajo la forma de una crónica doble, el personaje de don Pedro se asocia a un fatalismo que lleva al lector -en origen oyente- a imaginar, irremediablemente, un fin trágico e inevitable 3 . Enrique de Trastámara es el brazo ejecutor, pero los actos de don Pedro le excusan ${ }^{4}$. El discurso cronístico se centra, tras el regicidio de Montiel (1369), en relatar el modo en que la nueva dinastía se impuso por la fuerza de las armas. Cuando finaliza el polémico reinado de Enrique II, en el año 1379, Pedro López de Ayala cierra la crónica. En la siguiente, dedicada al reinado de Juan I (1379-1390), el discurso se construye a partir del entrelazamiento de diversas temáticas relacionadas, casi todas ellas, con los derechos de gobernación. El heredero de Enrique no se presenta como tal, sino como legítimo sucesor del linaje de La Cerda. El enlace entre su hijo y la nieta de don Pedro, Catalina de Lancáster, en 1388, zanja de manera definitiva el problema sucesorio.

Las crónicas de Pedro López de Ayala explican cómo llegó al trono y se consolidó la dinastía Trastámara. Parten de la idea de retomar el hilo cronístico interrumpido a mediados del siglo XIV y aplican un esquema organizativo que divide el discurso en años de reinado y éstos en capítulos, de tal modo que parecen presentarse a nuestros ojos como anales en los que las noticias son desarrolladas a través de una prosa seria, poco ornamentada, muchas veces lacónica. Todo ello da al relato una pátina de objetividad evidentemente buscada. Sabemos, sin embargo, que la naturaleza de la cronística castellana oficial, esto es, la escrita por mandato regio, es simultáneamente política e historiográfica. Por un lado, la cronística fue en la Castilla del siglo XIV un

3 Sobre el carácter de crónica doble del primer escrito véanse los estudios de ORDUNA, G., «Crónica del rey don Pedro y del rey don Enrique, su hermano, hijos del rey don Alfonso Onceno. Unidad de estructura e intencionalidad», en Actas del IX Congreso de la Asociación Internacional de Hispanistas (Berlín, 1986). Frankfurt-Main, Vervuert, 1989, pp. 255-262, y «La secuencia temporo-espacial en la estructura narrativa de la Crónica del rey don Pedro y del rey don Enrique, su hermano del Canciller Ayala», en Actas del VIII Congreso Internacional de la Asociación Hispánica de Literatura Medieval (Santander, 1999). Santander, Asociación Hispánica de Literatura Medieval, 2000, pp. XV-XXI.

4 Tal y como muestra Jorge N. Ferro, siete temas son los utilizados para desacreditar la legitimidad del rey en la crónica: el miedo de sus súbditos, la saña del monarca, las muertes que ordena, las faltas contra el código caballeresco, los vicios -y en especial la lujuria y la codicia-, el contraste entre "hacer su merced" y "el servicio del reino", y la voluntad de Dios que se manifiesta en diferentes avisos "lanzados" a don Pedro a lo largo de la crónica. Véanse FERRO, J.N., «El intertexto político en las crónicas del Canciller Ayala», en Incipit X, Buenos Aires, 1990, pp. 66-89, «La elaboración de la doctrina política en el discurso cronístico del canciller Ayala», en Incipit XI, Buenos Aires, 1991, pp. 28-72 y «Ética, política y lenguaje en textos medievales», en Incipit XV, Buenos Aires, 1995, pp. 115-138. 
instrumento propagandístico que asentaba en el pasado reciente las bases del presente en el que se escribía. Por otro, un registro de los sucesos elegidos para dar forma a la historia que se quería preservar; la que, según los criterios del autor, «merecía» ser registrada. Así, la presentación de don Pedro como un antimodelo de rey, el relato de las victorias de los sublevados y la introducción de determinados elementos legitimadores de la rebelión coexisten, en los textos, con la breve reseña de un suceso que no podía justificarse, pero tampoco podía dejar de señalarse; porque de otro modo habría sido imposible contar la historia ${ }^{5}$.

En los textos de Ayala la protagonista es la corte castellana, un organismo que fue creciendo en tamaño y complejidad a lo largo del siglo XIV. El rey es en el relato el centro de dicha corte, y el reino el espacio en el que se mueve. Los nobles y las ciudades, actores secundarios, se afanan por conseguir llegar a la privanza, en el caso de los primeros, y a ser cabeza de la Corona, en el de las segundas. La guerra es la temática fundamental y las batallas los episodios más detalladamente narrados. Esta representación de la realidad, necesariamente parcial y sesgada, aspira apenas a registrar una historia que pertenece a un todo mucho más complejo, del que pudieron extraerse muchas otras historias. Tomando distancia respecto al relato ayalino y adoptando otra perspectiva, puede afirmarse que en el año 1366 el reino de Castilla, gobernado por dos reyes, pasó a dividirse en dos bandos:

5 Sobre la obra de Ayala véanse, entre otros, los trabajos de GINGRAS, G.L., The Medieval Castilian Historiographical Tradition and Pedro López de Ayala's "Crónica del Rey D. Pedro", (tesis doctoral en ed. facsímil). Michigan, University Microfilms International, 1982, MITRE, E., «Tradición e innovación en la obra cronística del Canciller Ayala», en En la España Medieval 19, Madrid, 1996, pp. 51-76, ORDUNA, G., El arte narrativo y poético del Canciller Ayala. Madrid, CSIC, 1998, ESTEPA, C., «Rebelión y rey legítimo en las luchas entre Pedro I y Enrique II», en ALFONSO ANTÓN, M ${ }^{a}$ I., ESCALONA MONGE, J. y MARTIN, G., Lucha política: condena y legitimación en la España medieval. Annexes des Cahiers de linguistique et de civilisation hispaniques médiévales 16, 2004, pp. 43-62, y VALDALISO CASANOVA, C., «La dimensión política de la obra cronística de Pedro López de Ayala», en AMRAN, R. (coord.), Autour de Pedro López de Ayala. París, Indigo, 2009, pp. 189-202, y «La obra cronística de Pedro López de Ayala y la sucesión monárquica en la Corona de Castilla», en Edad Media, Revista de Historia, 12, Valladolid, 2011, pp. 193-211, y Historiografía y legitimación dinástica. Un estudio de la 'Crónica de don Pedro'. Valladolid, Universidad de Valladolid, 2011; así como los estudios de GÓMEZ REDONDO, F., Historia de la prosa medieval castellana II. El desarrollo de los géneros. La ficción caballeresca y el orden religioso. Madrid, Ed. Cátedra, 1999, «La construcción del modelo de crónica real», en FERNÁNDEZ ORDÓÑEZ, I. (dir.), Alfonso X el Sabio y las crónicas de España. Valladolid, Universidad de Valladolid, 2000, pp. 133-158, y «De la crónica general a la real. Transformaciones ideológicas en Crónica de tres reyes», en MARTIN, G. (ed.), La historia alfonsí: el modelo y sus destinos (siglos XIII-XV). Madrid, Casa de Velázquez, 2000, pp. 95-123. 
petristas y enriqueños. Ciudades e individuos se movieron entre uno y otro, obedeciendo a motivos muy diversos, hasta que Pedro I fue asesinado. A partir de ese momento, los que se negaron a aceptar a Enrique como rey formaron un partido que estuvo activo hasta el año del «entronque dinástico», 1388.

\section{LA GUERRA FRATICIDA, ANTESALA DEL PETRISMO}

Elegimos tomar como punto de partida para el estudio del petrismo la fecha del regicidio -el 23 de marzo de 1369- porque consideramos que fue sólo a partir de entonces cuando el problema sucesorio se planteó como tal. En los momentos anteriores, y concretamente en el período 1366-1369, lo que se estaba librando era una lucha entre dos monarcas, el legítimo y el autoproclamado, en el seno de la cual los miembros de la comunidad política cambiaban de bando a gran velocidad ${ }^{6}$. En líneas generales, puede decirse que en los meses que siguieron a la autoproclamación la mayor parte del reino se puso del lado de don Enrique, empujada por el hecho de que don Pedro había huido a Inglaterra. El nuevo rey se afanó a lo largo de ese tiempo en otorgar todo lo otorgable, aunque luego se vería obligado a desdecirse de gran parte de ello ${ }^{7}$. La desesperada búsqueda de apoyos, encaminada a atraer al máximo número posible de nobles y ciudades hacia su lado, dio pie a una política de «mercedes» que acabaría consolidándose ${ }^{8}$. Don Pedro, por su parte, compensaba también a aquellos que le apoyaban, ya fuese entregando territorios al rey Carlos de Navarra, en Libourne el 23 de septiembre de

6 A manera de ejemplo véase el caso de los Cisneros: «El compás marcado por el cambiante desarrollo de los acontecimientos, en no pocas ocasiones obligó a los miembros de la nobleza a tener que elegir o cambiar de bando. En lo que a los Cisneros respecta, se pueden apreciar dos etapas dentro de la contienda: una primera petrista en la que participó Juan Rodríguez, y otra segunda enriqueña cuyos protagonistas fueron su hermano y sus hijos. Ambas fases están separadas por un periodo de ocho años», en POZO FLORES, M., «El linaje palentino de los Cisneros en el siglo XIV: política y patrimonio», Publicaciones de la Institución Tello de Meneses, 80, Palencia, 2009, pp. 190-191.

7 Tal y como puede verse en la «Provisión real a los concejos del reino de Murcia y del obispado de Cartagena, comunicándoles su decisión de revocar todas las mercedes y donaciones hechas por él y por su esposa la reina» (Archivo Municipal de Murcia, Cartulario Real, fols. 27v.-28r.). Publicada en PASCUAL MARTíNEZ, L., Documentos de Enrique II. Murcia, 1983, pp. 52-54.

8 Sobre el posible origen en este período del modelo de «carta de merced» característico del siglo XV véase CARRASCO LAZARENO, M.T., «Aportación al estudio de los orígenes de las cartas de merced», en SIGNO. Revista de Historia de la Cultura Escrita, 5, Universidad de Alcalá, 1998), pp. 145-160. 
$1366^{9}$, ya concediendo, poco antes y en medio de su huida, al que acabaría siendo uno de los más destacados rostros del petrismo, Fernando de Castro, el título de conde de Trastámara, Lemos y Sarriá, el 27 de junio de 1366 en Santiago ${ }^{10}$ :

Por los muchos seruiçios e bonos que los de donde vos venides fesieron a los reyes donde yo vengo e vos fesieres e façedes de cada dia a mi, señaladamente en esta entrada que el traydor del conde don Enrrique fizo en los mis reynos, con muy grandes conpannas de franceses e yngleses e alemanes, e bretones e loynosines e gascones, e de otras muchas nasçiones para me deseredar, llamándose rey de los mis regnos, e faziendo mucho mal e dapno en la mi tierra, destroyendola fasta que los mas della se ouieron de alzar con el contra mi, vos, como bono e leal que sodes, touiestes vos e veniestes vos para Galisia por mi mandado e falastes con todos los prelados, e caualleros e escuderos, e con todos los de las villas e logares de Galisia, en manera que todos ellos touieron e tienen mi vos para mio seruiçio, por lo qual so tenudo de vos faser muchas e altas merçedes para que vos seades el mayor ome que nunca ouo en vuestro linage.

En la documentación procedente de las Cortes celebradas en Burgos, en febrero de 1367 , se hacen patentes tanto lo precario de la posición de don Enrique $^{11}$ como la penosa situación en la que se encontraba el reino ${ }^{12}$; y se

9 «Veyendo e conosçiendo que don Carlos, rey de Nauarra, nuestro bueno e leal amigo e pariente a tomado postura, porquel traidor del conde don Enrrique a ocupado nuestros regnos e tierras, nos a de ayudar a cobrar nuestros regnos, le ayamos fecho donaçion pura e irreuocable, que es llamada entre viuos». DÍAZ MARTíN, L.V., Colección Documental de Pedro I de Castilla (1350-1369), Vol. IV, pp. 245-246 (doc. 1351).

10 Publicado en DÍAZ MARTín, L.V., Colección Documental de Pedro I de Castilla (13501369), Vol. IV. Valladolid, Junta de Castilla y León, 1999, pp. 240-242 (doc. 1341).

11 «Por quanto nos ffeziemos estas dichas Cortes de priesa, por que tenemos de ffazer e de librar otras cossas algunas que son nuestro seruicio e pro e onrra de nuestros rregnos, et non podemos declarar algunas cosas que teníamos de ordenar». Fragmento extraído del «Ordenamiento de peticiones otorgado por D. Enrique de Trastámara en las Cortes que celebró en Burgos, después de haber sido proclamado rey por los de su partido en la era de MCCCCIV y fenecidas en la de MCCCCV (año 1367)», en Cortes de los Antiguos Reinos de León y de Castilla, publicadas por la Real Academia de la Historia. Tomo Segundo. Madrid, Imprenta y Estereotipia de M. Rivadeneyra, 1863, p. 155.

12 «Que todas las cibdades e villas e lugares e los que en ellos moran, anssy perlados e clerigos commo ffiios dalgo e caualleros e escuderos e de Ordenes e cibdadanos e todos los otros, que estan muy pobres por los grandes dapnos e males que han rescibido fasta aqui, e por los muy grandes menesteres que han auido, e por queles non fueron guardados los fueros e preuilleios e libertades e franquezas e otras cartas e mercedes que ovieron delos rreyes onde nos venimos, e buenos husos e buenas costunbres que auian en los tienpos pasados e les fueron quebrantados; e que nos pedien por merced que gelos mandasemos conffirmar e guardar», en Cortes de los Antiguos Reinos de León y de Castilla, t. II, p. 145. 
culpa de ello en parte a don Pedro, por las cargas fiscales que había impuesto, pero también a las tropas de mercenarios, «conpanas estranas», que habían llegado con Enrique de Trastámara ${ }^{13}$. Concebidas desde una perspectiva claramente propagandística, y reunidas en un momento en el que no era posible dar respuesta a todas las peticiones presentadas ${ }^{14}$, estas Cortes se centraron en subrayar la idea de que Enrique era el descendiente directo e inmediato sucesor de Alfonso XI. Para ello se trató de deslegitimar el reinado de don Pedro evitando registrar su nombre, no reconociendo los privilegios por él concedidos o $\operatorname{confirmados}^{15}$ y tachándosele de tirano ${ }^{16}$. Paralelamente, se subrayó la continuidad con los monarcas anteriores confirmando todos los privilegios concedidos por Alfonso XI y remitiendo como fuente legal al Ordenamiento de Alcalá y las Partidas ${ }^{17}$. También se incluyó una suerte de

13 «Otrossy alo que nos dixieron que por quanto la tierra estaua muy pobre e menesterosa e despoblada, por los grandes pechos e tributos queles fazia pagar aquel malo tirano que se llamaua Rey, e por aquellas conpanas estranas que venieron connusco en nuestro seruiçio, por quanto ffizieron muchos rrobos anssy de pan e vino e ganados commo de bestias e de otras cosas muchas, e mataron omes e mugeres, e prendieron e cohecharon a muchos, e los rredemyeron por muy grandes quantias de mr.», en Cortes de los Antiguos Reinos de León y de Castilla, t. II, pp. 145 y 146.

14 «Por el grant mester en que agora estamos contra los nuestros enemigos e delos nuestros rregnos, que non podemos agora librar nenguna cosa sobre esta rrazon; mays desque Dios quiera que estos fechos ayamos puestos en assessiego asy commo cunple a nuestro seruiçio, que mandaremos saber». Fragmento extraído del «Ordenamiento otorgado a petición de los caballeros y hombres buenos de la ciudad de Toledo en las Cortes de Burgos de la era de MCCCCV (año 1367)», en Cortes de los Antiguos Reinos de León y de Castilla, t. II, p. 157.

15 «A esto rrespondemos que nos plaze e quelo tenemos por bien, e que les sean conffirmados e guardados segund quelos ovieron delos rreyes onde nos venimos et juramos a Dios e alos santos Euangellios en la mano del dicho Arçobispo, que gelos guardemos e ffagamos guardar e conplir en todo segunt que en ellos se contiene; pero que tenemos por bien quelos preuilleios que dio aquel malo tirano que se llamaua Rey, que non ssean confirmados, e los quelos touieren vengan a nos e nos fazerles hemos merced», en Cortes de los Antiguos Reinos de León y de Castilla, t. II, p. 145.

16 Sobre los mecanismos de ilegitimación véanse VALDEÓN BARUQUE, J., «La propaganda ideológica arma de combate de Enrique de Trastámara (1366-1369)», en Historia, Instituciones, Documentos 19, Sevilla, 1992, pp. 459-467, RÁBADE OBRADO, M.P., «Simbología y propaganda política en los formularios cancillerescos de Enrique II de Castilla», en En la España Medieval 18, Madrid, 1995, pp. 223239, y VALDALISO CASANOVA, C., «La legitimación dinástica en la historiografía trastámara», Res publica 18, Murcia, 2007, pp. 307-321. Sobre los argumentos NIETO SORIA, J.M., "Rex inutilis y tiranía en el debate político de la Castilla bajomedieval», en FORONDA, F., GENET, J. et NIETO SORIA, J.M. (dir.), Coups d'Etat a la fin du Mogen Age. Madrid, Collection de la Casa de Velázquez, 2005, pp. 73-92.

17 «Conffirmamos todos los ordenamientos que el dicho Rey nuestro padre, que Dios perdone, mando fazer en las Cortes de Alcala. Et otrossy confirmamos las Partidas e las leyes que ffueron ffechas en el tienpo delos rreyes onde nos venimos, e mandamos 
indulto concedido a aquellos que, antes de que don Enrique fuese aceptado, le habían ofendido de palabra u obra; así como a los que habían cometido algún delito antes de que entrase en Castilla ${ }^{18}$. La primera parte de este indulto es para José Manuel Nieto Soria el punto de arranque en la utilización del «perdón real colectivo, dirigido a un grupo políticamente significado» como arma política ${ }^{19}$. En palabras del autor ${ }^{20}$.

Mediante la aplicación del perdón real como forma de, al menos, aparente liquidación de los conflictos se ofrecía una notable oportunidad a la transformación de la debilidad regia en un acto de representación de la afirmación de su poder. (...) Se entendía que los que habían adoptado tal posición (oponerse a don Enrique) no lo hacían porque dudaran de sus derechos o considerasen que el rey don Pedro estaba asistido por la razón, sino que lo hacían obligados por éste o por el temor que les inspiraba. Con ello, a la vez que el perdón partía de la supuesta ausencia de responsabilidad y de libertad de los perdonados, venía a transmitir la idea de que la mayor parte de los seguidores de don Pedro lo habían sido forzados por la propia actitud tiránica del monarca, lo que aportaba un criterio más de deslegitimación del rey precedente.

Con todo, tuvieron más fuerza las condenas por traición dirigidas a todo el que estuviese manteniendo desde Castilla contacto con el exiliado don Pedro ${ }^{21}$. La medida era necesaria y urgente, como prueba el contenido

que sean guardadas e conplidas ssegunt que se guardaron e conplieron en el tienpo del dicho Rey nuestro padre», en Cortes de los Antiguos Reinos de León y de Castilla, t. II, p. 145.

18 «Otrossy alo que nos dexieron que muchos omes assy perlados commo rricos omes e caualleros e escuderos ffiios dalgo, commo algunos delos omes bonos delas cibdades e villas e lugares de nuestros rregnos, que ovieron a ffazer e a dezir muchas cossas contra la nuestra persona, que non era nuestra pro nin nuestro sseruiçio, ante que nos entrasemos en este rregno, e quelo dezian e ffazian por mandado de aquel malo tirano que sse llamaua Rey, por miedo e rrecelo que auien del, ssy lo non ffeziesen e dexiesen; et que nos pedien por merced que perdonasemos a todos los delos nuestros rregnos en general toda la nuestra justicia para todos los maleficios muertes e rrobos e otras ocasiones que fizieron e dixieron en qual quier manera fasta aqui, del mayor caso ffasta el menor, et este perdon que ssea ffecho ffasta el dia de oy alos que estan en nuestro seruiçio, ssaluo ende aquellas personas que ffezieron e dixieron contra la nuestra persona o contra nuestro sseruicio ffablas o consseios despues que nos rregnamos aca desde que cada vnos nos rrecibieron por Rey e por Sennor por ssy e por sus procuradores; e que daqui adelante non ffeziessemos tales perdones nin mandasemos dar tales cartas nin alualas», en Cortes de los Antiguos Reinos de León y de Castilla, t. II, p. 147.

19 NIETO SORIA, J.M., «Los perdones reales en la confrontación política de la Castilla Trastámara», en En la España Medieval 25, Madrid, 2002, pp. 213-266.

20 Ibíd., pp. 218 y 227.

21 «Otrossy alo que nos dixieron queles ffizieran entender que algunos que venian con cartas de aquel tirano malo para algunas personas del nuestro ssennorio, et que 
del documento enviado por esas fechas -el 19 de febrero- por Pedro I a la ciudad de Murcia ${ }^{22}$.

Yo el rey fago saber a vos el conçejo, e alcaldes, e ofiçiales, e omes buenos de Murçia, que yo, e el prinçipe, e el rey de Nauarra somos ya juntos en vno e partimos desta tierra para entrar en Castiella e hemos de pasar los puertos eras sabado, e todas las conpañas pasan de cada dia quanto mas pueden. E si quisiere Dios de cobrar muy ayna mios regnos como cunple a mi onra e a mi estado. E ruegovos e mandovos que tomedes luego mi voz e vos alçedes con esa çibdat para mio seruiçio e fagades todo el mayor daño que pudieredes a todos los que non amaren mio seruiçio. E si algunos omes o [ ] cogedores e arrendadores y estan del traydor del conde prendeldos luego e teneldos presos e bien recabdados, e enbiadmelo dezir porque vos yo enbie mandar sobre ello como fagades.

Poco después tuvo lugar la batalla de Nájera, que permitió al monarca recuperar el trono y obligó a Enrique de Trastámara a huir, con lo que se repetía la misma situación, pero de manera inversa; y, de nuevo, se buscaban y premiaban las lealtades ${ }^{23}$, se castigaban las sediciones y se lidiaba con la

sse ffazian algunas ffabras que non eran nuestra onrra, nin guarda delos nuestros rregnos. Et que nos pedien por merced que ordenasemos en estas Cortes que todos aquellos omes e mugeres, christianos o judíos o moros, clérigos o rreligiosos o legos, de qualquier estado o condicion que ffuesen, que tales cartas traxiesen e rrecibiesen e las encubriesen, e ffabras ffiziesen o ffuesen en dicho o en ffecho o en conseio, que ffuesen por ello traydores, e [si] los podiessen auer, que ffuesen muertos por ello e quela muerte que ffuese de traydor, e quelos ssus bienes que ffuesen para la nuestra camara. Et otrossy aquellos que rreçibiesen las dichas cartas, quelos traxiesen ante nos o ante la nuestra justicia alos que gelas diesen so la dicha pena, e trayendolos, que ffuesen quitos por ello. Et que nos pedien por merced quelo judguemos e lo diesemos por sentencia en estas dichas Cortes», en Cortes de los Antiguos Reinos de León y de Castilla, t. II, p. 154.

22 Albalá de Pedro I al concejo, comunicando que está preparado para entrar en Castilla con el rey de Navarra y el príncipe de Gales; les ruega y ordena que tomen su voz y se alcen con la ciudad de Murcia en su servicio. (Archivo Municipal de Murcia, Cartulario Real 1367-1380, folio 1 r.). Publicado en Albalá de Pedro I al concejo, comunicando que está preparado para entrar en Castilla con el rey de Navarra y el príncipe de Gales; les ruega y ordena que tomen su voz y se alcen con la ciudad de Murcia en su servicio. Publicado en MOLINA MOLINA, A.L., Documentos de Pedro I. Murcia, Academia Alfonso X El Sabio, 1978, p. 196 (doc. 142).

23 En Burgos, a 29 de abril de 1367, el rey otorgaba una serie de villas a título de mayorazgo a Lope López de Haro, hijo de Martín López de Córdoba, «Por faser bien e mercet a vos, Lope Lopes de Haro, por grandes e muchos seruicios e leales e buenos que me fiso vuestro padre, don Martin Lopes (...), el qual salio de los mios regnos comido e estudo sienpre conmigo en quanto yo estoue fuera dellos e ante estungen despues me seruio e me sirue muy uien e lealmente, e tornose comigo a ellos e fue conmigo en la batalla que yo, e el Principe de Aquitania e de Gales, e los otros que uenien en mi aiuda ouimos con el traidor del conde don Enrique que solia ser de Trastamara, el qual, multiplicando traiçiones contra Dios e derecho contra rason, 
presencia en Castilla de tropas de mercenarios ${ }^{24}$. En un escenario tan difícil como este cualquier amenaza era duramente penada, directamente por el rey o con su apoyo. Así, ante la noticia de que en Murcia habían ejecutado a un traidor, el monarca respondía a 14 de mayo de ese mismo año del siguiente $\operatorname{modo}^{25}$ :

Vy vuestra carta en que me enbiastes dezir de como auiades tomado mi voz e vos auiades aleado con esa çibdat para mio seruiçio, e de como matarades al traydor de Ramon Oller, vuestro vezino, porque andaua diziendo e leuantando muchas maldades e trayçiones contra mio seruiçio, e pedricando a los omes por los enduzir que estudiesen e perseuerasen en su maldat teniendo voz del traydor del conde, e entendi todo lo que por la dicha vuestra carta me enbiastes dezir. Feziesteslo muy bien e tengouoslo en seruiçio, e bien çierto era yo e so de vos, que fariades por mio seruiçio quando lugar ouiesedes todo lo que vos pudiesedes, e que por vos non menguaria cosa, por lo qual so tenudo de vos fazer mucho bien e mucha merçed. (...) E a lo que dezides de la muerte de aquel traydor que me pediades por merçed que vos non fuese demandada, sabed que nunca vos sera demandada, mas antes vos

se auia puesto titulo e nonbre de rey en los dichos mios regnos, en la qual batalla por el poder e justicia de Dios fue bencido el dicho tridor e sus ayuntadores todos». Publicado en DÍAZ MARTíN, L.V., Colección Documental de Pedro I de Castilla (13501369), Vol. IV, pp. 256-258 (doc. 1367).

24 «E mando vos, que luego sin otro detenimiento ninguno, tomedes mi voz e guardedes esa villa para mio seruiçio [e prender] a todos aquellos que touieren voz del traydor del conde, e pongades todas las cosas que y estudieren del conde e de todos los otros que su voz tuoieren en recabdo. E vos faziendolo asi guardar vos hedes [ ] daño destas conpañas que aurien de yr alla sy lo asi non fiziesedes, que yo, vos aseguro por esta [mi carta que] vos non prendan, ni mate, ni lisie, ni mande prender, ni matar, ni lisiar, ni fazer otro mal alguno por este leuantamiento que contra mi fue fecho. E esto vos prometo como rey e señor de vos lo tener e guardar e cunplir [ ] quier que el principe a mandado que ninguna destas conpañas suyas non vayan alia sin su mandado porque [ ]. E mando vos que si alguna conpaña llegase que la non acojades y en la çibdat ni en ninguna de [ ] que vos veledes bien de noche e de dia en manera que vos non escalen parte a qualesquier que alla fueren asi [ ] gascones, e otros qualesquier de la conpaña del principe e de las otras conpañias que con el vienen que [ ] alguno ni algunos les fagan ni daño alguno e fazetles dar viandas e las otras cosas [ ] por sus dineros porque no ayan razon de voz fazer daño por las viandas que les non queredes [ ] daño vos fizieren enbiadmelo dezir e mostrar ca el principe porna en ello tal escarmiento» (Archivo Municipal de Murcia, Cartulario Real 1367-1380, folio 1 v.). Carta de Pedro I al concejo de Murcia, dando cuenta de la victoria que él y sus aliados han obtenido en Nájera sobre Enrique de Trastamara. Publicado en MOLINA MOLINA, A.L., Documentos de Pedro I, pp. 198 y 199 (doc. 144).

25 Archivo Municipal de Murcia, Cartulario Real 1367-1380, folio 3 v. Provisión de Pedro I al concejo y justicias de Murcia, mostrando su satisfacción por haberse alzado con la ciudad en su servicio, les declara libres de responsabilidad por la muerte de Ramón Oller por ser partidario de Enrique de Trastamara y les ordena poner paz en la ciudad y guardarla para su servicio. Publicado en MOLINA MOLINA, A.L., Documentos de Pedro I, p. 208. 
mando que a todos los traydores que acudieren alla en mio deseruiçio boluiendo esa tierra e esa çibdat a los (que) pudieredes tomar que los fagades la buena obra que feziestes aquel traydor, porque otros non se atreuan a fazer ninguna cosa contra mio seruiçio.

Añadiendo un mes más tarde, en otra misiva a la misma ciudad, que recibirían compensaciones por los servicios prestados ${ }^{26}$ :

E que fagades todo quanto mal e daños pudieredes a todos esos traydores que alla andan en mio deseruiçio, e a los que dellos touieren que los degolledes luego e les dedes muertes de traydores. Ca fio de Dios que muy ayna asosegare los mios regnos como cunple a mi onra e a mio estado. E ciertos sed que mi voluntad es de vos fazer muchas e altas mercedes e de vos otorgar muchas franquezas e libertades a vos e a todas las çibdades, e villas, e lugares de mios regnos que a tal tienpo como este se esmerare a guardar mio seruiçio, como ello es razon e derecho en manera que vos entendades que vos fago muy grant conosçimiento de todo lo que auedes fecho e fizieredes por mi seruiçio, desto sed bien ciertos e seguros sin dubda ninguna.

Las propiedades de los partidarios del enemigo eran entregadas a los fieles, que se apresuraban a venderlas, contando para ello con el apoyo de los monarcas. Cuando la ciudad tomaba la voz del contrario ello generaba graves problemas, como ya se había visto en las Cortes de Burgos de 1367 al plantearse la devolución a sus antiguos propietarios de los bienes expropiados por Pedro $\mathrm{I}^{27}$; y como se vería en repetidas ocasiones más a lo largo de los años siguientes ${ }^{28}$. Las condenas por traición, en forma de expropiaciones

26 Archivo Municipal de Murcia, Cartulario Real 1367-1380, folio 9r. Carta de Pedro I al concejo de la ciudad de Murcia, agradeciéndole los servicios que cada día le presta y comunicando que partía hacia Castilla para enfrentarse a su hermano Enrique de Trastamara; anuncia, también, que los reyes de Portugal y Granada acuden en su ayuda. Publicado en MOLINA MOLINA, A.L., Documentos de Pedro I, pp. 224-225.

27 «Otrossy alo que nos dixieron que muchos omes delos nuestros rregnos, por grand miedo del dicho tirano malo por algunas cosas que auian ffecho e dicho, que sse ffueran ffuera dela nuestra tierra a otras partes; e que por esto queles tomo ssus bienes e los dio a algunas personas, e que aquellos a quien los dio, que ganauan sus cartas para quelos conprasen premiosa mente algunos omes de algunas villas; e que nos pedien por mercet quelos que tales bienes premiosa mente comprasen, elos auemos mandado e mandaremos que daqui adelante quelos tornen aquellos a quien ffueron tomados, que mandasemos queles den e tornen los mr. que por ellos pagaron, e que gelos den aquellos que gelos vendieron o ssus herederos, o los que agora quissieren los dichos bienes, et ssy alguna meioria ffizieron en ellos, que gelo mandasemos pagar, e quelos ffrutos e rrentas que dellos han leuado, que non ffuesen tenudos de gelo tornar, pues los touieron en buen titulo», en Cortes de los Antiguos Reinos de León y de Castilla, t. II, pp. 147 y 148.

28 Como ocurrió, por ejemplo, cuando Juana Manuel dio al escribano Miguel Ruiz los bienes de Mencía López de Córdoba, el 30 de septiembre de 1367, «por quanto la dicha Mencía Lopes se fue para aquel malo tirano que sse llamaua rrey, e está con él 
y ejecuciones, y los perdones y mercedes, entendidos como medios para atraer apoyos, marcaron desde sus inicios el reinado de Enrique de Trastámara. Entre los años 1367 y 1369 surgieron también algunos de los rasgos que caracterizarían a los petristas, como el exilio, los apoyos de otros reinos y los intentos de hacer arder las hogueras de la sublevación en determinados lugares. Comenzaron a destacar, al mismo tiempo, determinados nombres de fieles. Cuando Pedro López de Ayala describe el regicidio el grupo que acompaña al monarca representa ya el germen del petrismo: «E vino con el rrey don Pedro esa noche don Ferrando de Castro e Diego Gonçalez, fijo del maestre de Alcantara, e Men Rodriguez de Senabria, e otros» ${ }^{29}$.

\section{2, EL PETRISMO EN LAS CRÓNICAS}

El primer capítulo de la crónica doble de Ayala dedicado en exclusiva a don Enrique (Año IV, capítulo 9) indica que la noche en que don Pedro fue asesinado se apresó a una serie de caballeros: Fernando de Castro, Men Rodríguez Sanabria, Diego González de Oviedo y Gonzalo González de Ávila, según una de las versiones de la crónica; Fernando de Castro, Fernán Alonso de Zamo-

en desçeruicio del rrey e mío». Documento publicado en VALDALISO CASANOVA, C., «La primera fase del proceso contra Pedro I de Castilla. Propaganda antipetrista en un documento de la catedral de Valladolid», en VAL VALDIVIESO, M.I. del y MARTÍNEZ SOPENA, P. (dir.), Castilla y el mundo feudal. Homenaje al profesor Julio Valdeón, Vol. II, Universidad de Valladolid, Junta de Castilla y León, 2009, pp. 573582. Algunas de estas expropiaciones fueron anuladas en el testamento de Enrique II, redactado el 14 de mayo de 1374: «Otrosi, por quanto nos tenemos cargo sobre nuestra anima de algunos logares e bienes que tomamos a algunas personas de nuestro señorio, mandamos e tenemos por bien que todos aquellos que fuere fallado por verdad que les nos tomamos e mandamos tomar sin razon e sin derecho, que les sean tornados a quien fueron tomados, o a sus herederos que les sea hecha enmienda por ello. Especialmente nos acordamos que tomamos algunos logares a doña Juana de Castro, a Men Rodriguez de Benavides, e a doña Maria, fija de don Alonso Fernandez Coronel, muger que fue de don Juan. E a estos sobredichos mandamos que todo lo que fuere fallado por verdad que les nos tomamos o mandamos toma de lo suyo, que les sea tornado e fecha emienda por ello; todavia tornando el dicho Men Rodriguez a Sant Estevan del puerto, e doña Juana a Villafranca de Valdecal, de que les ovimos fecho merced por emienda de lo que les ovimos tomado». Publicado en LLAGUNO, E., Crónicas de los Reyes de Castilla D. Pedro, D. Enrique, D. Juan I, D. Enrique III... con las enmiendas del Secretario Gerónimo Zurita y las correcciones y notas añadidas por Eugenio de Llaguno y Amírola. Madrid, Sancha, 1779-1793 (3 Vols.). Esta edición fue publicada de nuevo dentro de las Crónicas de los Reyes de Castilla, desde don Alfonso el Sabio hasta los Católicos don Fernando y doña Isabel, vol. 1, Colección ordenada por don Cayetano Rosell, Madrid, Ribadeneyra, 1875, y posteriormente impresa de nuevo en Madrid, Ed. Atlas, 1953.

29 Año XX (1369), capítulo 8. 
ra, Garci Fernández de Villodre y Gonzalo González de Ávila, según otra ${ }^{30}$. En ambos casos se añade «e otros», quedando así claro que el cronista elige citar sólo a algunos. Se dice también que, al día siguiente, los que estaban en el castillo de Montiel «vinieron a la merced» del rey Enrique y le entregaron «la cámara e joyas e dineros que allí tenían, que fueran del rey don Pedro». De todo ello se deduce que el grupo, aparentemente reducido, de hombres que acompañaron a don Pedro en la noche del regicidio fue retenido; mientras el resto de los partidarios del monarca que se encontraban en Montiel, incapaces de resistir, se rindieron. Caía así un bastión del legitimismo, pero restaban otros. Martín López de Córdoba y Mateo Fernández de Cáceres, privados de don Pedro, se refugiaron en Carmona, en donde estaban los hijos del monarca y su tesoro. En la zona noroccidental Zamora, Ciudad Rodrigo y gran parte de Galicia se negaron a dar por finalizada la guerra.

El cronista portugués Fernão Lopes aporta más detalles sobre los lugares que no quisieron aceptar a don Enrique ${ }^{31}$ :

Como el-rrei dom Pedro foi morto, algũus dos que tiinham os logares por elle tomarom voz por el-rrei dom Henrrique, outros, que lhe obedeecer nom quizerom, escreverom logo a el-rrei de Purtugall que sse sua mercee fosse de os aver por seus, que levantariam voz por elle, e que começasse entrar per Castella, e que lhe dariam as villas e o rreceberiam por senhor, fazendo d'ellas menagem. E as cidades e villas que tomarom sua voz forom estas: Carmona, Çamora, Cidade Rrodrigo, Alcantara, Vallença d'Alcantara; e mais, de Galliza, a cidade de Tui, Padrom, a Rrocha, a Crunha, Salvaterra, Bayona, Alhariz, Millmanda, Arahujo, a cidade d'Ourense, a villa de Ribadaiva, e Lugo, a cidade de Santiago, que sse deu mais tarde, e com certas condiçõoes.

Lopes ofrece a continuación un extenso listado de nombres de legitimistas que se exiliaron en Portugal, probablemente copiado de un documento que se habría redactado unos meses más tarde ${ }^{32}$ :

Sse veherom logo pera elle com suas gentes todollos fidallgos e cavalleiros que eram da parte d'el-rrei dom Pedro, assi de Galliza come de Castella, afora aquelles que estavom nos lugares que tomarom voz por Purtugall; e os

30 Existen dos versiones de la crónica doble, una considerada anterior, más breve, y conocida como versión Primitiva; y la repetidamente editada, denominada Vulgar. El fragmento que consultamos en ambas versiones en LLAGUNO, E., Crónicas de los Reyes de Castilla D. Pedro, D. Enrique, D. Juan I, D. Enrique III...

31 LOPES, F., Crónica de D. Fernando, edição crítica, introdução e índices de Giuliano Macchi. Lisboa, Imprensa Nacional - Casa da Moeda, 2007 ( $2^{a}$ edición, revisada), capítulo XXV.

32 Íbid. Algunos de estos personajes sólo llegaron al reino vecino más tarde. Un detallado seguimiento de los movimientos de los petristas en Portugal, basado en el relato cronístico, en FERNANDES, F.R., "Os exilados castellanos no reinado de Fernando I de Portugal», en En la España Medieval 23, Madrid, 2000, pp. 101-115. 
nomes d'algũus d'elles som estes: dom Affonso, bispo de Cidade Rrodrigo, que deu a el-rrei os castellos da Feolhosa e de Lumbrales, o conde dom Fernando de Castro, Alvoro Perez de Castro seu irmaão bastardo, que depois foi conde, o meestre d'Alcantara dom Pero Girom, Fernand'Afonso de Camora, Joham Affonsso de Beeça, Joham Affonsso de Moxica, Sueir'Eannes de Parada adeantado de Galliza, Gonçallo Martins de Laceres, Alvoro Meendez de Caceres, Affonsso Fernandez de Lacerda, Joham Perez de Novoa, Joham Perez Daça, Fernam Rrodriguez, Alvoro Rrodriguez seus irmaãos, Affonsso Fernandez de Burgos, Meem Rrodriguez de Seavra, Affonsso Lopez de Texeda, Affonso Gomez Churichaão, Diego Affonsso de Carvalhal, Gomez Garcia de Foyos, Martim Garcia d'Aljazira, Joham Fernandez Andeiro, Pedr'Affonsso Girom, Martim Lopez de Cidade, Affonsso Vaasquez de Vaamondo, Affonsso Gomez de Lira e Lope Gomez, Fernam Caminha e seus filhos, Dieg'Afonso de Proanho, Fernam Goterrez Tello, Diasanchez adeantado de Caçolla, Garcia Perez do Campo, Pero Diaz Pallameque, Diego Diaz de Gayoso, Fernand' Allvarez de Queiroos, Garcia Prego de Montaão, Diego Sanchez de Torres, Joham Affonsso de Çamora, Dieg'Affonsso de Bollanho, Andree Fernandez de Vera, Alvaro Diaz Pallaçoillo, Gonçallo Fernandez de Valladares, Bernald'Eanes do Campo, Martim Chamorro filho do meestre d'Alcantara. Estes e outros que nom nomeamos se veherom pera el-rrei dom Fernando, d'elles juntos em companhia e outros per ssi com suas gentes.

De acuerdo con el relato de Lopes, la intención primera del rey don Fernando era vengar la muerte de don Pedro quitándole el trono a su asesino $^{33}$; pero pronto comenzó a llamarse rey de Castilla ${ }^{34}$ e incluso a acuñar moneda en los lugares que se le entregaron ${ }^{35}$. Así se prolongaron las luchas, las ejecuciones y las confiscaciones ${ }^{36}$. Especialmente impactante parece haber

33 «El-rrei disse que de Castella seeria rrei quem Deus quisesse, mas que ell se trabalharia a todo seu poder de vingar a morte d'el-rrei dom Pedro seu primo». LOPES, F., Crónica de D. Fernando, capítulo XXV.

34 «Escrevendo a Çamora, chamava-sse rrei de Purtugall e do Algarve e da mui nobre cidade de Çamora, dizendo que per morte d'el-rrei dom Pedro seu primo elle era de dereito herdeiro dos rreinos de Castella e de Leom e seu senhor naturall». LOPES, F., Crónica de D. Fernando, capítulo XXVIII.

35 «Elle mandou fazer moeda de seus sinaaes, d'ouro e prata, e graves e barvudas em algũus logares dos que a sua voz tomarom, assi como em Çamora e na Crunha e em Tuy e em Vallença e em Miranda». LOPES, F., Crónica de D. Fernando, capítulo XXVIII. En las Cortes celebradas en Lisboa en el verano de 1371 se recoge una protesta al respecto, pues el rey había ordenado que esa moneda tuviese validez en todo el reino y después dejó de tenerla: "Artículo 34. Ao que dizem aos xxx e iiii arrtigos que a moeda que mandamos que sse fezese em Carmona e em crunha e em tuj que ualese per todo o noso Senhorio E que depois que a terra ffoj (chea della) mandamos que nom ualese». En Cortes portuguesas. Reinado de D. Fernando (1367-1383), Vol 1, Lisboa, Instituto Nacional de Investigação Científica - Centro de Estudos Históricos da Universidade Nova de Lisboa, 1990.

36 «Muitos veerom a elle d'essas villas e cidades, e pediam-lhe os bees dos que sse hiam pera el-rrei dom Henrrique (...) e pella guisa que el-rrei dom Fernando dava os bees 
sido el fin del cerco de Zamora pues, habiendo sido el lugar emplazado y el plazo agotado, la reina Juana Manuel mandó decir al caballero que estaba al frente, Alfonso López de Tejada, que si no entregaba la plaza mandaría degollar ante sus ojos a sus dos hijos, en poder de la reina; ante lo que Alfonso López respondió, de un modo que el cronista califica de «extraño, (...) no de alabar como virtud sino como hazaña sin provecho», que «con las mismas forja y martillo que había hecho aquellos, así haría otros». Los jóvenes fueron ejecutados y Zamora tomada poco después ${ }^{37}$.

Fernão Lopes sostiene que fueron los petristas quienes convencieron a don Fernando de que debía reclamar el trono de Castilla ${ }^{38}$ :

Aunque algunos dicen que él (don Fernando) no tomó en esta guerra otro título que el de vengador de la muerte del rey su primo, esto no fue así, pues hacían entender al rey, y él así lo decía, que dado que el rey don Pedro había muerto él era heredero directo de los reinos de Castilla y León como bisnieto legítimo del rey don Sancho de Castilla, nieto de la reina doña Beatriz que fue hija del rey don Sancho (...). Con todo, él nunca hubiese comenzado tal demanda ni buscado esta herencia tan lejana si no fuese por los lugares que se le dieron y los muchos hidalgos que se vinieron para él, y que le hacían entender esto.

Nos encontramos, por tanto, ante el retrato de un monarca influenciable, aconsejado por extranjeros y que antepone sus ambiciones al bienestar

d'aquelles que sse hiam e tiinham por parte d'el-rrei dom Henrrique, assi per este modo dava el-rrei dom Henrrique as terras e bees dos que tomavom voz por Purtugall, e os perseguia a todo seu poder». LOPES, F., Crónica de D. Fernando, capítulo XXVIII.

37 Fernão Lopes lo cuenta del siguiente modo: «Passou o termo antr'elles devisado e nom lhe veo outro nehũu acorro (...) e foi rrequerido Affonsso Lopez que desse o logar, pois o termo ja era passado; e ell se escusou per taaes pallavras, e com tall sõo que de o fazer avia pouca voontade; da quall cousa a rrainha ouve assi grande queixume que disse, afirmando per juramento, que sse lhe Affonsso Lopez nom desse o logar como ficara com ella, pois o termo já era passado, que lhe mandaria degollar os filhos ante seus olhos, $\mathrm{s}$ os ell oolhar quisesse; e assi lho mandou dizer. Affonsso Lopez, ouvindo aquesto, husou n'este feito d'hũu modo mui estranho, o quall nom he de louvar come virtude mas façanha sem proveito, comprida de toda cruelldade, e disse aaquelles que lhe esto disserom, que sse a rrainha por esta rrazom lhe mandasse degollar seus filhos, que ainda ell tinha a forja e o martello com que fezera aquelles, e que assi faria outros». LOPES, F., Crónica de D. Fernando, capítulo XLI.

38 «E posto que algũus digam que el nom tomou em esta guerra se nom titulo de vingador da morte d'el-rrei dom Pedro seu primo, esto nom foi d'esta guisa, mas faziam entender a el-rrei, e ell assi o dezia, que pois el-rrei dom Pedro era morto, que el ficava erdeiro nos rreinos de Castella e de Leom, ca era bisnieto legitimo d'el-rrei dom Sancho de Castella, neto da rrainha dona Beatriz filha do dito rrei dom Sancho (...) porém ell nunca se tremetera de começar tall demanda nem buscar esta avoenga de tam longe, se nom forom os lugares que sse lhe derom de seu grado e os muitos fidallgos que sse veherom pera elle, que lhe esto faziam entender». LOPES, F., Crónica de D. Fernando, capítulo XXX. 
del reino. Es, y conviene tenerlo muy presente, el retrato trazado décadas después por el cronista de la dinastía que se impondría tras la muerte de don Fernando, deslegitimando los derechos de su heredera ${ }^{39}$, por lo que su objetivo era narrar el reinado de tal modo que la guerra con Castilla pareciese un error. En contrapartida, la crónica de Pedro López de Ayala trata de los enfrentamientos armados que condujeron a la definitiva toma de poder y consolidación de la dinastía Trastámara: hasta 1371 se centra en los focos legitimistas existentes dentro de Castilla y en los ataques portugueses, en 1372 habla de diferentes ataques petristas, en 1373 de la guerra con Portugal y en 1374 de la tentativa del duque de Lancáster de entrar por la fuerza en el reino; pero en adelante no dice nada más sobre el tema, que sólo retomará en la crónica correspondiente al reinado de Juan I. El cotejo de las crónicas de Ayala y Lopes muestra que no se contradicen, pero tratan temáticas diferentes. Aunque la guerra sea la materia común, y aunque Lopes utilizara los textos de Ayala como fuentes, el portugués pretendía relatar al detalle los errores de un monarca, y el castellano las victorias de otro.

El episodio de la caída de Carmona es especialmente significativo en ambos relatos. En sus últimos meses de vida Pedro I había abastecido la villa para refugiarse allí, con sus hijos, sus allegados y las familias de éstos, en caso de peligro extremo. Tras la muerte del rey Carmona, defendida por Martín López de Córdoba, resistió dos años. El relato de Lopes sobre los momentos anteriores a la caída comienza recordando que los refugiados se habían hecho vasallos del rey portugués ${ }^{40}$ y continúa indicando que, ante la amenaza de un nuevo cerco, le pidieron ayuda enviando a un mensajero ${ }^{41}$. Don Fernando se excusa, y el caballero le acusa de no cumplir lo pactado, mostrándole un documento que tenía en su poder, en el que el monarca les prometía socorrerles si eran cercados, y reprochándole «que si ellos hubiesen sabido que

39 Véanse, entre otros, REBELO, L.S., A concepção do poder em Fernão Lopes, Lisboa, Livros Horizonte, 1983, y AMADO, T., Fernão Lopes, Contador de História: sobre a Crónica de D. João I. Lisboa, Editorial Estampa, 1991 y O Passado e o Presente. Ler Fernão Lopes, Lisboa, Presença, 2007.

40 «Assi que morto el-rrei dom Pedro, como dissemos, estava Martim Lopez de Cordova meestre de Callatrava em Carmona com muitas gentes consigo; e quando os outros logares tomarom voz por el-rrei dom Fernando, foi esta villa de Carmona huu d'elles, segundo ouvistes; e screverom-lhe loguo como estavom alli juntos e prestes pera seu serviço, e que sse acontecesse que os el-rrei dom Henrrique vehesse cercar, que lhe pediam por mercee que llhes acorresse, como aaquelles que de toda voontade queriam seer seus». LOPES, F., Crónica de D. Fernando, capítulo XLV.

41 «Souberom como el-rrei dom Henrrique hordenava de os hir cercar, e enviarom a pressa huu cavalleiro a el-rrei dom Fernando pera lhe fazer saber come el-rrei de Castella juntava suas gentes pera viir sobr'elles». LOPES, F., Crónica de D. Fernando, capítulo XLV. 
no les ibais a socorrer hubiesen asegurado sus vidas de otro modo, y no se habrían puesto en peligro de muerte y deshonra, como están ahora ${ }^{42}$. Ayala relata del siguiente modo el fin del cerco $^{43}$ :

Ya las viandas fallesçian a los de dentro; otrossi muchos que estauan con Martin Lopez se partian dende e se venian para el rrey. E Martin Lopez desque vido que non se pudian mas defender e que non auia acorro ninguno de Ingla terra nin por Castilla nin de Granada, traxo su pleytesia con el rrey don Enrrique (...) que daria presso a Matheos Ferrandez de Caçeres (...) e que el dicho Martin Lopez fuesse en saluo e el rrey lo pusiesse en otro rregno do el quisiesse o le fiziesse merçed sy con el quisiese fincar. E al rrey don Enrrique plogo esta pleytesia e fizolo assy. E fue fecha jura a Martin Lopez por el maestre de Santiago Ferrand Osores, que el rrey don Enrrique le guardaria el seguro que le auia fecho. E desque todo esto fue assi hordenado e ouo entregado e conplido el dicho Martin Lopez todo lo que prometiera al rrey, el rrey mandolo prender e desque fue tomado preso leuaronlo a Seuilla. E por quanto el rrey lo auia sentençiado (...) fizolos matar en Seuilla a el e a Matheos Ferrandez. Enpero algunos que amauan el serviçio del rrey, especial mente don Ferran Osores, maestre de Santiago, fue muy quexado e le non plogo, por quanto el rrey le mandara que assegurasse de muerte al dicho Martin Lopez, e quexose mucho dello al rrey; pero non le pudieron aprouechar al dicho Martn Lopez que non muriesse.

Leonor López de Córdoba, hija de Martín López, lo contaría con más detalle años después ${ }^{44}$.

42 «Prometestes aaquelles nobres homees que estam em Carmona e teem vossa voz de lhes acorrerdes se fossem cercados, tanto que vo-llo fezessem saber, segundo he conteudo em este vosso alvará (...) ca se elles souberom que lhe vos nom aviees d'acorrer, elles segurarom suas vidas per outra guisa, e nom forom postos em periigo de morte e desonrra como ssom ora; mas elles, penssando de seerem per vos deffesos como era rrazom, vos derom a villa e se oferecerom a morrer por vosso serviço, nom curando as aveenças nem preitesias que lhe el-rrei dom Henrrique prometia com muito as proll e honrra, as quaaes lhe agora de mui maa mente faria, por a sanha que já d'elles tem». LOPES, F, Crónica de D. Fernando, capítulo XLV. A diferencia de don Fernando, el rey de Granada sí intento auxiliar a los de Carmona: «E dizem aqui alguus que sabendo el-rrei de Graada como os filhos d'el-rrei dom Pedro estavom assi cercados, que viinha com muita gente de pee e de cavallo pera lhes acorrer; e que viindo no estremo lhe disserom como era tomada Carmona e os filhos d'el-rrei dom Pedro presos, e que estonce se tornou pera Graada». LOPES, F, Crónica de D. Fernando, capítulo XLVI.

43 Año VI, capítulo 2.

44 «Memorias de Leonor López de Córdoba», en Colección de Documentos Inéditos para la Historia de España, vol. 81. Madrid, 1842-1895, pp. 33-44. El relato continua: «Y yéndole acortar la cabeza encontró con Mosen Beltrán de Clequin, caballero francés, que fue el caballero que el Rey Don Pedro se había fiado del que lo pornía en salvo, estando cercado en el castillo de Montiel; y no cumpliendo lo que le prometió, antes le entregó al Rey Don Enrique para que lo matase; y como encontró á el Maestre, díjole: "Señor Maestre, ¿no os decía yo que vuestras andanzas habían de parar en esto?" Y él respondió: "Más vale morir como leal, como yo lo he hecho, que no vivir como vos"». 
Y el Señor Rey Don Enrique, visto este fecho y que no podía por fuerzas de armas entrarla a satisfacerse de esto hecho, mandó al Condestable de Castilla tratase de medios con mi padre. Y los medios que mi padre trató fueron dos: el uno, que las Señoras Infantas las habían de poner libres a ellas y a sus tesoros en Inglaterra, antes que él entregase la dicha villa al Rey. Y ansí fue hecho, porque mandó a unos escuderos, deudos suyos naturales de Córdoba y de su apellido, que fuesen con ellas, y la demás gente que le pareció. El otro capítulo fue que él y sus hijos y valedores y los que habían asistido por su orden en aquella villa, fuesen perdonados del Rey, y dados por leales a ellos y á sus haciendas; y así se le dio firmado del dicho Condestable, en nombre del Rey. Y hecho este partido, entregó la villa al dicho Condestable en nombre del Rey; y de allí fueron él y sus hijos y la demás gente a besar la mano del Rey. Y el Señor Rey Don Enrique mandolos prender y poner en las Atarazanas de Sevilla; y el dicho Condestable, visto que el Señor Rey Don Enrique no le había cumplido la palabra que él había dado en su nombre al dicho Maestre, se salió de su Corte y nunca más volvió a ella. Y el Señor Rey mandó que le cortasen la cabeza a mi padre en la plaza de San Francisco, de Sevilla, y que le fuesen confiscados sus bienes y los de su yerno, valedores y criados.

Pedro López de Ayala omite tanto los detalles de la ejecución como la no-intervención de Portugal a favor de los de Carmona, pero no calla que don Enrique faltó a lo pactado. El monarca sabía que el castigo a los rebeldes debía ser duro y ejemplar; muestra de ello es que en las firmas, ese mismo año, de paces con Portugal el rey se había negado a negociar nada que tuviese que ver con los de Carmona ${ }^{45}$. Las luchas, con todo, continuaron. Fernando de Portugal siguió manteniendo a los petristas que vivían en su reino ${ }^{46}$, y enviando dinero a los que combatían fuera de é $1^{47}$, hasta que tuvo noticia de

45 «Foi mais firmado antre os rreis ambos que el-rrei dom Fernando abrisse maão e desemparasse todollos logares e terras que ell e aquelles que sua voz mantiinham cobrarom do senhorio de Castella (...) e perdoarom d'huua parte aa outra, des o caso mayor ataa o mehor, a todollos que em serviço dos senhores andarom e sse alçarom com villas e castellos e tomarom voz contra elles; e ficarom os rreis a lhe entregar todos os seus bees de rraiz, salvo se foi aos de Carmona, que ainda em este tempo tiinham voz por Portugall, posto que ja tenhamos escripto sua tomada d'ella, por os quaaes el-rrei dom Fernando fez muito por entrarem em este trautos, e nunca el-rrei de Castella em ello quis conssentir, dizendo por escusa que perdoar aos de Carmona era cousa per que sse podia rrecrecer gram desvairo antr'elle e el-rrei dom Fernando; mas que a molher do conde dom Fernando de Castro com seu filho e companha e cousas suas sse fosse a Portugall pera seu marido ou onde lhe prouguesse». LOPES, F, Crónica de D. Fernando, capítulo LIII.

46 "Os seus aviam casas e terras em que abastadamente podessem viver, e os que viinham desacorridos aviiam mester bem apousentados e fazer-lhes muitas mercees». LOPES, F., Crónica de D. Fernando, capítulo XXVII.

$47 « \mathrm{E}$ aos que nom eram presentes, mandavom-lhe o solldo aos logares onde estavom, assi como a Garcia Fernandez de Villa Odre, que estava no rreino de Murça, que avia de servir com quatrocentas lanças, e a Diego Lopez de Montoyo e a outros fidallgos». LOPES, F., Crónica de D. Fernando, capítulo L. 
la demanda de Juan de Gante, casado con Constanza de Castilla. Al saberlo el rey portugués descargó su furia con Fernando de Castro ${ }^{48}$ :

Y aún más os digo que yo no fui bien avisado de ese hecho, ni tampoco los de mi consejo (...) porque si hubiese sabido que el duque de Lancáster se llamaba rey de Castilla y su mujer reina, os habría dicho que os fueseis todos para él y que él viniese a demandar el reino, si por derecho le pertenecía; y habría sido mejor que gastar mis reinos y gente como los he gastado.

En marzo de 1373 don Fernando, para poner fin a su enfrentamiento con Enrique de Trastámara, firmó en Santarém un tratado por el cual se comprometía a expulsar de su reino a los petristas ${ }^{49}$, excluyéndose a algunos que pudieron quedarse en Portugal ${ }^{50}$. Tras unas leves resistencias iniciales, los legitimistas acabaron por aceptar encontrarse en Gibraltar con las naves del rey de Granada, para desde allí partir con ellas al reino de Valencia ${ }^{51}$.

$48 \ll \mathrm{E}$ ainda mais vos digo que eu nom fui bem avisado em tall feito, nem isso meesmo os do meu consselho, em cometer tall guerra quall fui começar: porque s'eu aa primeira bem cuidara como sse o duque d'Allancastro chamava rrei de Castella e sua molher rrainha, dissera a vos outros que vos forees todos pera elle, e que ell vehesse demandar o rreino, se lhe per dereito perteencia; e em isto fezera melhor siso que gastar meus rreinos e gente como gastei e comprar omezio de que nom veho proveito mas mui grand perda». LOPES, F, Crónica de D. Fernando, capítulo LXXXVI.

49 "Que do dia d'esta paz firmada ataa trinta dias seguintes el-rrei dom Fernando lançasse fora do seu rreino, das pessoas que sse pera elle veherom de Castella, estas aqui nomeadas: dom Fernando de Castro, Suer'Eanes de Parada, Fernand'Afonso de Çamora, os filhos d'Alvaro Rrodriguez Daça, Fernam Rrodriguez e Alvaro Rrodriguez e Lopo Rrodriguez, Fernam Goterrez Tello, Diego Affonso do Carvalhal, Diego Sanchez de Torres, Pedr'Afonso Girom, Joham Affonsso de Beeça, Gonçallo Martiiz, e Alvoro Meendez de Caceres, Garcia Perez do Campo, Garcia Mallfeito, Gregorio e Fillipote ingreses, Paay de Meira dayam de Cordova, Martim Garcia d'Aljazira, Martim Lopes de Cidade, Nuno Garcia seu irmaão, Gomez de Foyos, Joham do Campo, Bernalld'Eanes seu irmaão, Joham Fernandez d'Andeiro, Joham Focim, Fernam Perez e Afonso Gomez Churrichaãos. Estas viinte e oito pessoas, e mais nom, nomeu el-rrei de Castella que fossem lançados fora de Portugall, segurando-os per mar e per terra, ataa seerem postos em salvo». LOPES, F., Crónica de D. Fernando, capítulo LXXXII.

50 «E deu el-rrei de Castella lecença, ante que passassem os trinta dias, que ficassem em Portugall em serviço d'el-rrei dom Fernando Sueir'Eannes de Parada e Gonçallo Martinz e Alvoro Meendez de Caceres e Nuno Garçia de Cidade e Martim Garçia d'Aljazira e Gregorio Lombardo e Garcia Perez do Campo: e de todo esto ouve el-rrei dom Fernando escripturas por sua guarda e segurança». LOPES, F., Crónica de D. Fernando, capítulo LXXXIV.

51 «Outorgarom de sse partir; e el-rrei disse que os mandaria honrradamente como compria a suas honrras e lhes faria muitas mercees; e assi o fez, ca mandou logo armar duas gallees e certas naaos, as quaees prestes em Lixboa, se forom todos meter em ellas; e muitos dos outros que nomeados nom eram partirom estonce em sua companha, sentiindo-o por mais seu proveito que ficar no rreino, aos quaaes chamavom perjurados, porque tiinham da parte d'el-rrei dom Pedro». LOPES, F, Crónica de D. Fernando, capítulo LXXXVI. 


\section{EL PETRISMO EN EL MARCO DE LA CULTURA POLÍTICA}

El panorama al que se enfrentó Enrique de Trastámara tras el regicidio fue sintetizado por José Luis Martín del siguiente modo ${ }^{52}$ :

El control de los partidarios de Pedro es, lógicamente, la primera preocupación del nuevo monarca; pero tan importante o más que la pacificación interior era poner coto a las ambiciones de los monarcas peninsulares que aspiraban a compartir el reino de Castilla con Enrique y presionaban apoyando ahora a los petristas: Carlos II de Navarra reclamaba Logroño, Vitoria, Salvatierra y Santa Cruz de Campezo; Pedro el Ceremonioso de Aragón pretendía ampliar el reino de Valencia con tierras murcianas y ocupar algunas plazas fronterizas entre Aragón y Castilla; Fernando de Portugal se consideraba con más derechos al trono de Castilla que el conde de Trastámara, hijo ilegítimo de Alfonso XI, y los musulmanes de Granada se consideraban desligados de las treguas y paces firmadas con Pedro I; a estos problemas se añaden la necesidad de pagar los servicios de las compañías francesas y evitar una posible intervención inglesa. Combatir a los enemigos y pagar a los amigos exige medios económicos de los que Enrique no dispone y que obtendrá o intentará obtener aumentando los impuestos y vendiendo o dando en pago de los servicios prestados diversos lugares de realengo, es decir, mediante lo que conocemos como «mercedes enriqueñas», a las que Pedro López de Ayala alude de pasada para recordar que esta práctica era peligrosa por cuanto enajenaba el apoyo de «muchas comarcas del Regno que tovieron su voz». Enrique acudirá también a la confiscación de los bienes de los rebeldes y a la acuñación de moneda de baja calidad.

Por lo general la Historia trata de reconstruir el pasado para comprenderlo; pero en ocasiones a esa comprensión se llega mejor reflexionando sobre lo que no ocurrió. Dadas las circunstancias en las que Enrique de Trastámara accedió al trono, y la situación en la que se encontraba el reino, fue todo un logro conseguir que los otros señoríos peninsulares no se hiciesen con territorios; o que algún otro no lograse arrebatárselo. Para impedirlo se hizo necesario fomentar la cohesión, mantener un diálogo abierto con dicho reino, buscar su apoyo. Veámoslo analizando una serie de misivas enviadas por el monarca a la ciudad de Murcia entre los años 1370 y 1371, y en las cuales se contienen al menos tres tipos de argumentos propagandísticos: los destinados a minimizar al contrario, los que buscaban subrayar la legitimidad del rey y los dedicados a ensalzar sus victorias. El 13 de abril de 1371 Enrique de Trastámara escribía a Murcia, desde Medina del Campo, tras haber interceptado unas cartas enviadas por un tal «miçer Gaspar» al rey de Granada y a dos

52 MARTÍN, J.L., «Defensa y justificación de la dinastía Trastámara. Las Crónicas de Pedro López de Ayala», en Espacio, Tiempo y Forma, Serie III, Historia Medieval t. 3, Madrid, 1990, p. 164. 
conocidos petristas $^{53}$. La carta del rey respondía a la petición de la ciudad de conocer la situación, y lo hacía restando importancia a la fuerza de sus contrarios, despreciando sus «nueuas astrosas e mintrosas», y confiando en que «por la merçed de Dios e por el buen derecho que tenemos» acabaría vengándose de «todos aquellos que non quisieren ser nuestros amigos e andudieren en mentira e en falsedat». En este escrito para Enrique sus enemigos son los que no quieren ser sus amigos; es decir, los que buscan segregarse en lugar de aceptar sus intentos de integración. Aplicando una perspectiva un tanto maniqueísta, el rey entendía que, estando él «en la merced de Dios» y teniendo «buen derecho», los otros vivían en la mentira y la falsedad. Para combatirles, don Enrique pedía ayuda al reino, «sy plazer nos auedes de fazer ${ }^{54}$;

53 «Otrosy a lo al que nos enbiastes dezir de las cartas que fueron tomadas que enbiaua miçer Gaspar al rey de Granada e a Ferrant Perez Caluiello e a Johan Alfonso de Baeça, sabed que Alfonso Yañez Fajardo nos enbio los traslados dellas e en verdat por las sus nueuas astrosas e mintrosas nos damos muy poco, ca fiamos por la merçed de Dios e por el buen derecho que tenemos que todos aquellos que non quisieren ser nuestros amigos e andudieren en mentira e en falsedat que nos auremos grant venganza dellos». Provisión-carta misiva al concejo de Murcia, comunicándole estar informado de los acontecimientos ocurridos con los reyes de Aragón y de Granada (Archivo Municipal de Murcia, Cartulario Real, fols. 31v.-32r.). Publicada en PASCUAL MARTíNEZ, L., Documentos de Enrique II, pp. 69 y 70.

54 «Fazemos vos saber que nos auemos sabido por çierto en commo el traydor de Lope Diaz de Baeça e otro que llaman Gil Sanchez de Vbeda, que tenie atestar, que salieron el otro dia de Carmona e se fueron para el rey de Granada et el rey de Granada, commo nuestro amigo e por la paz que es entre nos e el, non los quiso reçebir antes les mando que se fuesen luego fuera del su reyno et ellos quesieron se yr para Portogal, saluo que ge lo non consentio, et agora nos han dicho por çierto en commo los dichos Lope Diaz e Gil Sanchez e otros que son fasta vnos veynte de cauallo que tienen acordado de se yr e que han a pasar el rio por y çerca de Murçia e saltar en Aragon. Porque vos mandamos e rogamos que luego en punto vista esta nuestra carta pongades buenas guardas en todos los pasos de todas esas trauesias et aperçebid todos los lugares de toda esa comarca por do entendieredes que prouaran a pasar que non sean tomados et ha menester, sy plazer nos auedes de fazer, que esto que lo fagades asy». Sevilla, 2 de noviembre de 1370. Provisión real al concejo de Murcia, mandándole poner guardas en la travesía del río para impedir que algunos traidores pasasen al reino de Aragón (Archivo Municipal de Murcia, Cartulario Real, fol. 37v.). Publicada en PASCUAL MARTÍNEZ, L., Documentos de Enrique II, pp. 91 y 92. Un contenido similar aparece en otra misiva posterior: «Fazemos vos saber que a nos han enbiado dezir ommes çiertos de Aragón en commo Garçia Ferrandez de Villaodre e Ferrant Perez Caluiello e algunos ommes desa çibdat traen sus trabtos por la dar al rey de Aragon e que por esta razon el rey de Aragon es venido al regno de Valencia, la qual cosa en ninguna manera que sea nos non la podemos creer mas antes tenemos que vosotros, commo buenos e leales que vos sodes, que guardaredes todo lo que fuere nuestro seruiçio. Porque uos mandados, sy seruiçio nos queredes fazer, que querades poner buen recabdo en esa çibdat et la mandedes velar e guardar muy bien en manera que ella este todauia bien guardada commo a nuestro seruiçio cunple et eso mesmo que acuçiedes dello al conde don Johan Sanchez. Et otrosy que fagades quanto pudieredes por saber sy 
pero, cuidándose de no mostrar debilidad, también informaba al detalle de sus triunfos ${ }^{55}$ :

Fazemos vos saber que en jueues seys dias deste mes de março en que estamos ouiemos vna carta de la reyna donna Johanna mi muger, por la qual nos enbio dezir que miercoles veynte e seys dias del mes de febrero que agora paso la çibdat de Zamora, que estaua alçada, se entrego e tomo nuestra voz. Et otrosy que acogieron dentro a todos los nuestros que estauan fuera, pero que ya antes desto el alcaçar de la dicha çibdat estaua por nos. Otrosy todos los mas e mejores que en la dicha çibdat auie estaban aca fuera en nuestro seruiçio e commoquier que los de dentro eran rebeldes fasta agora non lo fazian saluo por reçelo de lo que auian fecho non por otra cosa ninguna, et bien creed que la çibdat esta ya sosegada en tal manera commo cunple a nuestro seruiçio et esto vos enbiamos dezir porque somos bien çierto que tomaredes en ello grand plazer.

En este breve relato de la toma de Zamora, que sobrepasa las dimensiones de una noticia, el monarca dejaba claro que «los más e mejores» de la ciudad estaban de su parte, y los que resistían, calificados como «rebeldes», «non lo fazian saluo por reçelo de lo que auian fecho, non por otra cosa ninguna»; es decir, actuaban así por miedo a las represalias. Muy similar es la carta en la que, el 25 de marzo de ese mismo año, don Enrique explicaba porqué había ido a cercar Carmona, así como en qué punto se hallaban las conversaciones con Portugal ${ }^{56}$ :

Et otrosy sabed que nos çercamos esta uilla de Carmona e asentamos real sobrella este viernes que paso, que fueron veynte e vn dias deste mes de março, et çercamosla por dos cosas: lo vno porque nos sabemos bien ciertamente que tan poca es la vianda que los de dentro tienen que por ninguna manera

ay algunos que tales fechos commo estos andan trabtando et aquellos que sopieredes que lo fazen que los fagades luego echar fuera de la çibdat, et sobresto nos enbiamos alla a Johan Sanchez, nuestro escriuano, para que fable con busco et mandamos vos que le creades de todo lo que uos dixiere de nuestra parte». Real sobre Carmona, 25 de marzo de 1371. Carta misiva al concejo de Murcia, mandándole dar creencia a su escribano, Juan Sánchez, y guardar y vigilar la ciudad, pues algunos traidores andan en tratos con el rey de Aragón para que entre en ella (Archivo Municipal de Murcia, Cartulario Real, fol. 39r.). Publicada en PASCUAL MARTÍNEZ, L., Documentos de Enrique II, pp. 101 y 102.

55 Sevilla, 6 de marzo de 1371. Carta misiva al concejo de Murcia, en que le comunica que se ha entregado la ciudad de Zamora (Archivo Municipal de Murcia, Cartulario Real, fol. 38r.). Publicada en PASCUAL MARTíNEZ, L., Documentos de Enrique II, p. 98.

56 Carta misiva al concejo de Murcia, mandándole dar creencia a su escribano, Juan Sánchez, y guardar y vigilar la ciudad, pues algunos traidores andan en tratos con el rey de Aragón para que entre en ella (Archivo Municipal de Murcia, Cartulario Real, fol. 39r.). Publicada en PASCUAL MARTÍNEZ, L., Documentos de Enrique II, pp. 101 y 102. 
que sea fasta comer los que y estan e avn todos los mejores dellos no mas de la quinta parte deuen comer pan e agua e non tienen al que non han viandas que les ahondar puedan fasta el dia de Pascua que son doze dias, e lo otro porque el traydor de Martin Lopez quiere se yr dende e leuar consigo los fijos de Pero Gil e poner y bien que avnque ellos se quieran yr que lo non puedan fazer, asy que fiamos en Dios que para este tienpo del dia de Pascua la villa sera nuestra e todos los que en ella estan vernan a nuestras manos avnque non quieran.

Et otrosy de los fechos de Portogal sabed quel delegado don Alfonso Perez de Guzman e otrosy el conde de Portogal estan avn en vistas por asosegar los nuestros fechos e del rey de Portogal et bien creemos sin ninguna dubda que se faga la paz, ca pues, loado sea Dios, todos nuestros fechos se enderezan muy bien de cada dia. Otrosy auemos ya cobrado a Zamora et toda aquella comarca esta ya desenbargada e sosegada muy bien commo cunple, avunquel non quiera abra de venir a todo lo que nos quisieremos.

Unos días más tarde las paces con Portugal estaban firmadas ${ }^{57}$, y no mucho después el monarca podía informar ya de la toma de Carmona ${ }^{58}$ :

Fazemos vos saber que oy sabado, diez dias andados desde mes de mayo, cobramos esta villa de Carmona et, maguer que andauan en sus pleitesias connusco, tamanno fue el desacuerdo que ouo en todos ellos que non quisieron esperar dichas pleitesias, saluo los vnos que se salieron a la nuestra merçed e los otros que tomaron nuestra voz en la uilla, en tal manera que nos acojeron luego en ella e nos entregaron luego el alcaçar que dizen de la reyna e el alcaçar de la puerta de Seuilla, e el traydor de Martin López des que se vio perdido encerrose con muy pocos en el otro alcaçar del rey et estos que se encerraron con el han nos enbiado dezir questa noche o eras por todo el dia nos entregaran el dicho traydor muerto o biuo e eso mesmo a los fijos de Pero Gil e a todo el algo que y esta. Otrosy eso mesmo la muger de don Ferrando de Castro e sus fijos estan ya en nuestro poder para fazer

57 «Fazemos vos saber que oy jueues, tres dias deste mes de abril en que estamos ouiemos carta del delegado del Papa e otrosy de don Alfonso Perez de Guzman en que nos enbiaron dezir en commo las pazes son ya firmadas e sosegadas entre nos e el rey de Portogal, las quales sed ciertos que se fizieron mucho a onrra nuestra e de los nuestros regnos, pero que en estas pazes non entraron estos traydores de Carmona los quales, con las merced de Dios, nos entendemos tomar mucho ayna que por cosa que sea non se nos puedan mas defender et sed ciertos que desta vez el rey de Portogal finca por nuestro amigo verdaderamente para nos ayudar contra todos los del mundo, et estas nueuas vos enbiamos dezir porque somos ciertos que tomaredes con ellas grand placer». Real sobre Carmona, 3 de abril de 1371. Provisión carta misiva al concejo de Murcia, comunicándole que han sido firmadas las paces con Portugal (Archivo Municipal de Murcia, Cartulario Real, fol. 39v.). Publicada en PASCUAL MARTÍNEZ, L., Documentos de Enrique II, p. 103.

58 Provisión real al concejo de Murcia, comunicándole que había sido ocupada la villa de Carmona (Archivo Municipal de Murcia, Cartulario Real, fol. 40r.). Publicada en PASCUAL MARTíNEZ, L., Documentos de Enrique II, p. 105. 
dellos lo que la nuestra merçed fuere, et estas nueuas vos enbiamos dezir porque somos ciertos que vos plazera.

La división dentro de la villa había precipitado su caída. De nuevo, la mayor parte de los rebeldes querían irse a la merced de Enrique, y el «traydor» Martín López de Córdoba le sería pronto entregado, vivo o muerto. Los mecanismos utilizados por el rey para sofocar las ininterrumpidas rebeliones pasaban, así, por la lucha armada, el perdón a los que se le entregaban y el castigo a los que se mantenían en su contra. A medida que fue ganando fuerzas, don Enrique pudo permitirse mostrar menos clemencia con las amenazas, ordenando que con aquellos que se unían a los petristas, o se mantenían en contacto con ellos, fuese «fecha justiçia en manera que mueran en tal manera porque ninguno non se atreua a andar en ninguna cosas de las que son contra nuestro seruiçio ${ }^{59}$. Se asiste así al progresivo fortalecimiento de una monarquía nacida en el seno de un conflicto y que, pese a la escasez de apoyos y a los ataques, consiguió imponerse. Observado de otro modo, se contempla la llegada al poder y el ascenso de una dinastía en el marco del conflicto, y gracias a él.

Los trabajos centrados en el análisis de la cultura política en este período ven en el conflicto una de las expresiones de dicha cultura, y en su estudio una manera de aproximación al análisis del proceso de construcción de la

59 «Fazemos saber al conceio e oficiales e ommes buenos de la noble çibdat de Murçia, que vimos la carta que nos enbiastes e vimos todo lo que por ella nos enbiastes dezir et tenemos vos en seruiçio todo lo que nos enbiastes aper çebir de los fechos de alla, et mandamos vos que lo fagades asy daqui adelante, que sienpre nos enbiedes aperçebir de todas las cosas que alla recrecieren que entendieredes que cunplen a nuestro seruiçio. Otrosy sabed que nos dixieron que algunos ommes dende que se fueron aca con el traydor de Ferrand Perez Caluiello agora quando vernia a Guardamar e Alicante, e esto non entendemos que cunpla a nuestro seruiçio en los yr ningunos a uer sabido que Ferrand Perez e Garçia Ferrandez que son muy grandes traydores et andan tratando todauia todas la cosas que ellos pueden contra nuestro seruiçio. Porque vos mandamos que luego syn detenemiento ninguno sepades quales se fueron a uer con el dicho Ferrand Perez et les fagades luego prender e poner en buen recabdo a ellos e a todos sus bienes et nos lo enbiedes luego dezir, que nos mandamos sobrello lo que la nuestra merçed fuere. Otrosy vos mandamos que todos aquellos que fallaredes e sopieredes son de los dichos Ferrand Perez e Garçia Ferrandez o de algunos de aquellos que estan $n$ nuestro deseruiçio que se fueron alla con ellos, que sean luego presos e tomados todos sus bienes e los bienes que los pogades en buen recabdo con escriuano publico, et dellos mandamos que sea luego fecha justiçia en manera que mueran en tal manera porque ninguno non se atreua a andar en ninguna cosas de las que son contra nuestro seruiçio. Et non fagades ende al por ninguna manera so pena de la nuestra merçed». Toledo, 20 de julio de 1371. Albalá al concejo de Murcia, mandando prender a los que habían hablado con el traidor Ferrand Pérez Calvillo (Archivo Municipal de Murcia, Cartulario Real, fol. 40v.). Publicada en PASCUAL MARTíNEZ, L., Documentos de Enrique II, p. 105. 
monarquía ${ }^{60}$. Cuando se observa el conflicto como expresión de cultura política sus manifestaciones pueden dividirse en dos tipos: las que formaron parte del enfrentamiento armado propiamente dicho y las de naturaleza retórica. En el caso de los Trastámara las primeras representan, al ser narradas o enumeradas, la historia de la larga derrota del petrismo; mientras las segundas, mucho más complejas, ofrecen al historiador la posibilidad de analizar la, tantas veces denunciada, parcialidad de las fuentes. En la mayor parte de los casos, tras el desenlace de un conflicto el poder, la gloria y la fama quedan en manos del vencedor, restando para los perdedores el silencio y el olvido. Sin embargo, en muchas ocasiones los nombres de los vencidos quedaron registrados para engrandecer la victoria, o justificarla. Tal es el caso de la cronística, analizada en las páginas anteriores, que representa en sí misma una manifestación retórica del conflicto. Determinados elementos presentes en la documentación conservada también lo son. La aparición de petristas en la documentación enriqueña obedece, fundamentalmente, a dos causas: o bien eran perdonados, o bien condenados. En ambos casos su mención era una muestra de la autoridad del monarca, revelada tanto a través de la gracia como de la capacidad para ejecutar. Las referencias a los petristas se encuadran en el contexto de la propaganda enriqueña, dirigida al reino que don Enrique gobernaba y destinada a reforzar su posición ${ }^{61}$.

Como puede notarse, se parte aquí de la idea, muy presente en la historiografía contemporánea, de que existió una «monarquía Trastámara»; es decir, de que entre los siglos XIV y XVI o, más concretamente, entre los reinados de Enrique II y los Reyes Católicos, se desarrolló en Castilla una forma

60 NIETO SORIA, J.M., «El conflicto como representación: expresiones de la cultura política Trastámara», en NIETO SORIA, J.M (dir.), El conflicto en escenas. La pugna política como representación en la Castilla bajomedieval. Madrid, Sílex, 2010, pp. 15-55.

61 El principal objetivo de la propaganda es el logro de la obediencia consentida, pues cuando se obtiene el consentimiento se gana la adhesión, tal y como señalara FORONDA, F., «Sociedad política, propaganda monárquica y régimen en la Castilla del siglo XIII. En torno al Libro de los Doze Sabios», en Edad Media. Revista de Historia 7, Valladolid, 2005-2006, pp. 13 y 14. Sobre este tema véanse NIETO SORIA, J.M., «La realeza», en NIETO SORIA (dir.), J.M., Orígenes de la monarquía hispánica: propaganda política y legitimación (ca. 1400-1520). Madrid, Ed. Dykinson, 1999, pp. 25-60; NIETO SORIA, J.M., «Más que palabras. Los instrumentos de la lucha política en la Castilla bajomedieval», en DE LA IGLESIA DUARTE, J.I. (coord.), Conflictos sociales, políticos e intelectuales en la España de los siglos XIV y XV (Actas de la XIV Semana de Estudios Medievales, Nájera, 4 a 8 de agosto de 2003). Logroño, Instituto de Estudios Riojanos, 2004, pp. 165-204, y los trabajos reunidos en NIETO SORIA, J.M. (dir.), La monarquía como conflicto en la Corona castellano-leonesa (c. 1230-1504), Madrid, Ed. Sílex, 2006, y en especial NIETO SORIA, J.M., «La monarquía como conflicto de legitimidades», pp. 13-71 y CARRASCO MANCHADO, A.I., «El conflicto como representación», pp. 489-546. 
concreta de dominación de la comunidad política. En consecuencia, los estudios de la llamada "Castilla Trastámara» remiten a una cronología que comporta la aceptación de una proposición normalmente enunciada como corolario: desde el año 1369 y hasta la llegada de los Austrias se gestó y evolucionó en la Corona castellana un método de gobierno con unas características y expresiones no necesariamente exclusivas, pero sí propias. Lejos de discutir si puede hablarse o no de la «monarquía Trastámara» como un todo coherente, si los reyes del período tuvieron tendencias «absolutistas» o «autoritarias», o si se estaba caminando hacia la creación del llamado «estado moderno», quisiéramos aquí resaltar que el petrismo fue, de cualquier modo, la primera contestación a esa monarquía y, en cierto modo, uno de sus principales determinantes. Dentro del juego político, los movimientos de integración y segregación de los petristas, piezas y peones en posiciones variables, acabaron marcando las directrices de los Trastámara. Cronológicamente su propia existencia define un período de asentamiento, definición y consolidación de la institución monárquica. Cabe subrayar que en ningún momento se planteó la desintegración de la Corona, la elección de un monarca que no descendiese de reyes castellanos o el cuestionamiento de la monarquía. La crisis sirvió, a la larga, para reforzar a la institución; y ello fue posible gracias a los movimientos, las acciones y las decisiones de los primeros reyes de la dinastía.

\section{HACIA UNA HISTORIA DEL PETRISMO}

La lectura de los relatos cronísticos muestra que hubo un primer período de conflicto que finalizó con la caída de Carmona, en 1371; una segunda etapa que acabó con la expulsión, exigida en el Tratado de Santarém, de los legitimistas castellanos de Portugal; una década de resistencia desde el exilio, interrumpida por dos años de ofensivas desde Inglaterra, con el apoyo del rey don Fernando (1381-1383); un paréntesis tras la muerte del monarca; y una invasión inglesa que llevó al Tratado de Bayona, firmado en 1388. Dentro de estas fases, seis en total, las dos primeras son las más confusas, pues no existía una alternativa clara al gobierno Trastámara; mientras en las siguientes las demandas de Juan de Gante, duque de Lancáster, en su propio nombre o en el de su esposa Constanza, definieron un tipo de conflicto muy diferente, en el que todos los opositores se aliaron, directa o indirectamente, con el candidato inglés.

Cabe preguntarse si en las primeras fases de su existencia se puede hablar de los petristas como un grupo, en mayor o menor medida cohesionado, con unos objetivos concretos y unas características que les unan; más allá de la 
pertinaz resistencia a aceptar a Enrique de Trastámara como rey. Conviene, de entrada, notar que la palabra «petrista» no está registrada en los escritos del período. En las crónicas y los documentos se habla de «emperegilados» o «emperogilados», esto es, de partidarios de Pero Gil; nombre dado a don Pedro en las primeras etapas de la guerra para deslegitimar su gobierno apelando a una historia infundada, creada por la propaganda enriqueña, según la cual la reina doña María había dado a luz a una niña en vez de a un varón y había cambiado al bebé por un recién nacido de origen judío ${ }^{62}$. Se habla también de «perjurados» ${ }^{63}$, en oposición a los «enricados ${ }^{64}$, pero creando además un paralelismo con la idea de «perjuro» o jura en falso. Todo ello muestra que la mayor parte de la información que poseemos acerca de los petristas, al menos en lo que respecta al período 1369-1373, procede del lado enemigo. Ello obliga, en cierto modo, a hacer una historia del primer petrismo «en negativo».

El listado más amplio que conservamos de los petristas es el que aparece en la crónica de Fernão Lopes cuando se recogen los nombres de los castellanos que, tras el regicidio, se exiliaron en Portugal ${ }^{65}$. Se ha indicado que el grueso de estos nombres pertenecía a nobles ligados a Fernando de Castro ${ }^{66}$, una de las cabezas más visibles del partido petrista, fallecido en el exilio en 1375 y enterrado en Bayona con una inscripción sobre su tumba: «toda la lealtad de España» ${ }^{67}$. Tras desnaturalizarse del rey en 1354 para no ser acusado de traición al colaborar en la rebelión de la nobleza, Fernando de Castro regresó, arrepentido, al lado de don Pedro y no le abandonó en ningún momento, dando muestras de una fidelidad inquebrantable. Apresado en Montiel tras el regicidio, consiguió huir cuando acompañaba, en calidad de prisionero, a las tropas enriqueñas en el cerco de Guimarães, en diciembre de 1369. Desde ese momento se colocó al frente de los petristas que residían en Portugal, viéndose obligado a abandonar el reino en virtud de los acuerdos firmados en el Tratado de

62 RÍOS y RíOS, A. de, «Cómo y porqué se llamó a D. Pedro el Cruel Pero Gil», en Boletín de la Real Academia de la Historia, 36, 1900, pp. 58-65.

63 LOPES, F., Crónica de D. Fernando, capítulo LXXXVI.

64 «E quando el-rrei dom Fernando chegou a terra antre os seus, disse com geesto ledo contra eles: "Quanto eu hanrricado venho!". E esto dezia elle porque a todollos que tiinham com el-rrei dom Henrrique chamavom hanrricados». LOPES, F, Crónica de D. Fernando, capítulo LXXXII.

65 Véase nota 32.

66 FERNANDES, F.R., «Os exilados castellanos no reinado de Fernando I de Portugal», pp. 108 y 109.

67 La noticia de la muerte de Fernando de Castro la da Ayala en la crónica de Enrique II (Año X, capítulo 2). 
Santarém. Su biografía es, sin duda, todo un ejemplo de lo que pudo ser el perfil de un petrista ${ }^{68}$.

Junto a Fernando de Castro, el cronista Pedro López de Ayala cita a cinco hombres más presentes en el regicidio: Men Rodríguez Sanabria, Diego González de Oviedo, Fernán Alonso de Zamora, Gonzalo González de Ávila y Garci Fernández Villodre. Todos consiguieron liberarse y huir, los tres primeros a Portugal y los dos últimos a Aragón; lugares desde donde se mantuvieron fieles a la causa. El hecho de que estos personajes se encontrasen junto al monarca en el momento en que trataba de huir del cerco de Montiel indica que estaban muy próximos al rey. Martín López de Córdoba, otro de los privados de don Pedro, se dirigía también hacia Montiel en esos momentos pero, como ya se indicó, la noticia de la muerte del monarca hizo que regresase a Carmona, en donde resistió junto a Mateo Fernández de Cáceres ${ }^{69}$. Los orígenes de todos estos personajes son bastante dispares, pues abarcan desde un aristócrata -Fernando de Castro- hasta un burócrata -Mateo Fernández. Podría decirse que lo único que tenían todos ellos en común era la privanza con don Pedro; y deducirse que fue allí en donde se generó el embrión del petrismo. Creemos, sin embargo, que no fue ése el verdadero origen del núcleo de fieles a la causa.

Cuando Enrique de Trastámara entró en Castilla, en 1366, Pedro I huyó a Inglaterra y permaneció allí hasta reunir, junto al Príncipe de Gales, el ejército que atravesó los Pirineos y venció en la batalla de Nájera. El acuerdo firmado en Libourne, el 23 de septiembre de 1366, para establecer las condiciones de la ayuda inglesa, exigía que algunos de los privados que

68 En relación con Fernando de Castro, GONZÁLEZ, A., «Pedro I de Castilla y Galicia», Boletín de la Universidad Compostelana 64, Santiago de Compostela, 1956, pp. 241-276; LÓPEZ FERREIRO, A., Historia de la iglesia de Santiago de Compostela. Santiago, 1903; GARCÍA ORO, J., La nobleza gallega en la baja Edad Media. Santiago de Compostela, Bibliófilos Gallegos - Biblioteca de Galicia, 1971; GARCÍA ORO, J., Galicia en la baja Edad Media. Iglesia, señorío y nobleza. Santiago de Compostela, Bibliófilos Gallegos Biblioteca de Galicia, 1977, y PARDO DE GUEVARA Y VALDÉS, E., Los señores de Galicia. Tenentes y condes de Lemos en la Edad Media. La Coruña, Colección Galicia Histórica, 2000.

69 Sobre Martín López de Córdoba véanse DÍAZ MARTÍN, L.V., «La elección de Martín López de Córdoba como maestre de Calatrava», en Studia Silensia. Homenaje a Fray Justo Pérez de Urbel. Burgos, Diputación Provincial y Abadía de Santo Domingo de Silos, 1976, tomo I, pp. 423-432; MOLINA MOLINA, A.L., «Don Martín López de Córdoba, maestre de las órdenes de Alcántara y Calatrava y Adelantado Mayor del Reino de Murcia», en Miscelánea Medieval Murciana 4, Murcia, 1978, pp. 87-105 (el mismo artículo en Anuario de Estudios Medievales, 11, Madrid, 1981, pp. 87-105); DÍAZ MARTÍN, L.V., Los oficiales de Pedro I de Castilla; CABRERA SÁNCHEZ, M., «El destino de la nobleza petrista: La familia del maestre Martín López de Córdoba», en En la España Medieval, 24, Madrid, 2001, pp. 195-238. 
habían acompañado a don Pedro, o sus familiares, se quedasen en Inglaterra como rehenes, junto con las hijas del monarca. Comenzó a crearse allí, en ese período de permanencia de don Pedro en Aquitania y en los meses que lo siguieron, la base de las futuras relaciones de los petristas con la familia real inglesa. Tras la victoria de Nájera, el Príncipe de Gales, desconfiando del monarca, ideó apartar a Pedro I del trono y crear una regencia que, bajo su tutela, gobernase Castilla hasta que la sucesión estuviese garantizada. Dicho consejo tendría la forma de un triunvirato formado por Fernando de Castro, Martín López de Córdoba y Garci Fernández Villodre. El primero había encabezado la lucha en Castilla mientras don Pedro estaba en Inglaterra, y los otros dos habían acompañado al rey en su huida ${ }^{70}$. Los planes del Príncipe no fueron adelante; pero los nombres de los elegidos coinciden con los de las tres principales cabezas del futuro petrismo. Puede, por tanto, decirse que el origen del movimiento se encuentra en este punto; esto es, en el momento en que los principales privados de Pedro I, en colaboración con los hijos del rey de Inglaterra, comienzan a gestar una alternativa de gobierno que mantenga a Enrique de Trastámara alejado del trono, con o sin don Pedro a la cabeza. En las dos décadas siguientes su afán, y el de aquellos que les sucedieron, fue llevar a buen término esos planes.

\section{CONCLUSIONES}

La historia del petrismo está intrínsecamente unida al complejo proceso de consolidación de la dinastía Trastámara. A lo largo de ese tiempo, y en los primeros momentos con el apoyo del resto de los reinos peninsulares, los adalides del legitimismo trataron de recuperar la corona castellana para el rey Fernando I de Portugal, nieto de Sancho IV, o Juan de Gante, casado con la para muchos heredera, Constanza de Castilla. Sus nombres son citados esporádicamente en las crónicas ayalinas, con mayor frecuencia en las portuguesas, y de vez en cuando, pero de manera muy irregular, en la documentación. Son, en buena medida, los olvidados, los perdedores, los vencidos. También, visto desde otra perspectiva, los incorruptos, los leales, los fieles a una causa. Para reconstruir sus pasos se hace preciso trazar un mapa en el que aparezcan todos los reinos ibéricos y las posesiones de la Corona de Inglaterra, incluida Aquitania; y también consultar fuentes de muy diversa procedencia. Es, además, necesario tener en cuenta que el conflicto petristas-enriqueños

70 Todo ello en RUSSELL, P.E., A Intervenção Inglesa na Península Ibérica durante a Guerra dos Cem Anos. Lisboa, Imprensa Nacional Casa da Moeda, 2000 (1 ${ }^{a}$ edición: The English Intervention in Spain and Portugal in the time of Edward III and Richard II. Oxford, Clarendon Press, 1955). 
se proyectó sobre los dos grandes conflictos occidentales del momento, la Guerra de los Cien Años y el Cisma de la Iglesia.

El contexto político que condiciona y explica la existencia de los petristas, esto es, la por ellos buscada y tenazmente mantenida prolongación de la guerra fraticida, es un marco idóneo para analizar los mecanismos de integración y segregación utilizados por la monarquía bajomedieval castellana para asentar sus bases. A lo largo del conflicto sucesorio tanto Enrique II como Juan I combinaron acciones integradoras con decisiones segregadoras. Dentro de las primeras, repetidos intentos de hacer que ciudades y nobles rebeldes pasasen a formar parte del todo constituido por el reino que gobernaban, se encontraban las mercedes, los perdones reales y algunos pactos políticos. Las segundas, destinadas a separar y marginar tanto a los sublevados como a aquellos que representaban un peligro para la dinastía, incluyeron desde expropiaciones hasta ejecuciones, pasando por encarcelamientos temporales o perpetuos. La lucha armada, la resistencia y el exilio fueron las respuestas obligadas de los que se negaron a unirse a su proyecto político. En este pulso mantenido a lo largo de dos décadas puede medirse la fuerza que en cada momento tuvieron los llamados «reyes nuevos», cabezas visibles de una dinastía ilegítima que con el tiempo consiguió imponerse en la Península asentándose en Castilla, gobernando después en Aragón y cimentando mediante acuerdos matrimoniales la utópica «unión ibérica». Los primeros pasos de esta aparentemente imperfecta monarquía, en permanente construcción, fueron dados en el siglo XIV en el seno de un conflicto generado por su ilegitimidad. 